УДК: 37.014:005.6

Хоружий Костянтин Сергійович

аспірант

НПУ ім. М. П. Драгоманова, м. Київ, Україна

kothor88@gmail.com

\title{
ЗМІСТ МЕТОДИКО-ТЕХНОЛОГІЧНОГО ЗАБЕЗПЕЧЕННЯ ІНФОРМАЦІЙНОӤ СИСТЕМИ УПРАВЛІННЯ ЯКІСТЮ ОСВІТИ МАЙБУТНІХ ЕКОНОМІСТІВ
}

\begin{abstract}
Анотація. У статті розглянуто зміст і сутність організаційної роботи щодо застосування методико-технологічного забезпечення інформаційної системи управління якістю освіти (ICУЯО) майбутніх економістів. Зміст організаційної роботи щодо упровадження методикотехнологічного забезпечення ICУЯО майбутніх економістів включає чотири етапи (підготовчий, інструктивно-адаптаційний, методично-базовий та експериментальноевалуаційний) та містить сукупність методико-технологічних заходів для кожного з етапів упровадження ІСУЯО. Визначено основні етапи, комплекс методів і послідовність організаційних заходів упровадження методико-технологічного забезпечення ICУяО. Досліджено педагогічний вплив запропонованої методики застосування ICУЯО на формування професійної компетентності студентів економічних спеціальностей.
\end{abstract}

Ключові слова: інформаційна система управління якістю освіти; зміст методикотехнологічного забезпечення; організаційна робота; підготовчий; інструктивноадаптаційний; методично-базовий; експериментально-евалуаційний етапи; комплекс методів; методико-технологічні заходи.

\section{1. ВСТУП}

Постановка проблеми. Подальший розвиток вітчизняної системи освіти у сучасних умовах реформування освітньої галузі потребує удосконалення системи національного моніторингу й оцінювання якості освіти і прискорену інформатизацію системи освіти відповідно до вимог Закону України «Про вищу освіту» [1]. Національною стратегією розвитку освіти в Україні на період до 2021 року [2] визначені стратегічні напрями державної політики у сфері освіти, серед яких важливе місце займає модернізація структури, змісту та організації освіти на засадах компетентнісного підходу, а також ії інформатизація.

Аналіз останніх досліджень i публікацій. Результати аналізу наукової літератури засвідчують, що проблемам якості економічної освіти і моніторингу якості фахової підготовки спеціалістів, формам і методам освітніх вимірювань, використанню сучасних інформаційних технологій в освіті приділялась належна увага 3 боку вітчизняних і зарубіжних учених. Педагогічний аспект підвищення якості освіти у контексті інформаційно-комунікаційного підходу досліджено В. Ю. Биковим, Б. С. Гершунським, М. І. Жалдаком, І. П. Підласим, В. П. Сергієнком, Н. Ф. Тализіною та ін. Педагогічна діагностика у контексті використання перспективного сучасного інструментарію педагогічних вимірювань системно відображена в роботах В. С. Аванесова, Л. І. Білоусової, Ф. Бейкера, Ф. Брауна, Ю. О. Жука, Л. А. Зайцевої, Дж. Равена, Б. Райта, Н. Розенберга, П. Ротаєнко, В. П. Сергієнка, М. Стоуна, О.Г. Шмельова та ін. Проблемі використання інформаційних технологій в освіти присвячені праці В. Ю. Бикова, А. М. Гуржія, М. І. Жалдака, Ю. О. Жука, Т. І. Коваль, А. Ф. Манако, С. А. Ракова, В. М. Кухаренко, В.В. Олійника, О. В. Співаковського, О. М. Спіріна та ін. Залучення сучасних технологій щодо використання соціальних 
Інтернет-сервісів в освітньому просторі опрацьовано С. Дауном, К. Йодіке, Дж. Сіменсом, С. Патаракіним, Е. Шоппом, Б. Ярмаховим та ін.

У той же час, проблема формування і застосування методико-технологічного забезпечення інформаційної системи управління якістю освіти майбутніх економістів потребує проведення подальших досліджень.

У попередніх публікаціях автора розглянуто сучасні вимоги до системи управління якістю освіти в контексті вітчизняного і світового досвіду [3], досліджено проблеми й особливості формування інформаційної системи управління якістю освіти майбутніх економістів, а також представлено її компонентну структуру й обгрунтовано зміст компонентів, що входять до їі складу [4]. Проте, питання сутності організаційної роботи щодо застосування методико-технологічного забезпечення інформаційної системи управління якістю освіти (ICУЯО) майбутніх економістів розглянуто недостатньо і тому потребує подальшого дослідження.

Пріоритетом розвитку як економічної освіти, так i освіти в цілому, $\epsilon$ впровадження сучасних інформаційно-комунікаційних технологій, а також створення системи інформаційно-аналітичного забезпечення у сфері управління навчальними закладами і проведення моніторингу якості освіти [5].

3 огляду на вищезазначене, проблема розробки, упровадження та організачіi ефективного застосування методико-технологічного забезпечення інформаційної системи управління якості освіти майбутніх економістів у процесі фахової підготовки $\epsilon$ вельми своєчасною й актуальною. Адже Закон України «Про вищу освіту» [1] встановлює вимоги до системи забезпечення якості вищої освіти, яка передбачає забезпечення наявності методико-технологічного забезпечення щодо інформаційних систем для ефективного управління освітнім процесом.

Актуальність проблеми застосування методико-технологічного забезпечення інформаційної системи управління якості освіти майбутніх економістів обумовлюється необхідністю оновлення економічної освіти у контексті розроблення новітніх наукових підходів (інформаційно-комунікаційного, компетентнісного, особистісноорієнтованого), надання їй нового змісту, сенсу та вимірів. Відповіддю на виклики сучасності, що містяться у зазначених вище нормативно-правових документах, $\epsilon$ упровадження методико-технологічного забезпечення ІСУЯО, що відповідає актуальним вимогам розвитку національної вищої школи.

Мета статті. Метою дослідження є визначення змісту і сутності організаційної діяльності щодо упровадження методико-технологічного забезпечення ICУяО майбутніх економістів.

\section{2. МЕТОДИ ДОСЛІДЖЕННЯ}

Серед обраних методів дослідження доцільно виділити такі:

- аналіз науково-теоретичних джерел;

- конкретизація етапів організаційної роботи щодо застосування методикотехнологічного забезпечення ІСУЯО;

- методи педагогічної діагностики;

- узагальнення змісту і сутності методико-технологічного забезпечення ICУ ЯО.

\section{3. РЕЗУЛЬТАТИ ДОСЛІДЖЕННЯ}

Упровадження методико-технологічного забезпечення ICУЯО відбувалось відповідно до організаційно-цілеспрямовуючого, когнітивно-компетентнісного та 
звітно-контрольного структурних компонентів [4]. Сутність організації упровадження методико-технологічного забезпечення полягає у логічному конструюванні подальшої експериментальної роботи, забезпеченні цілісності й динамічності ICУЯО майбутніх економістів у процесі тї застосування.

3міст організаційної роботи щодо упровадження методико-технологічного забезпечення передбачав такі позиції:

- визначення етапів щодо упровадження методики застосування ICУяО майбутніх економістів; окреслення комплексу методико-технологічних заходів для кожного 3 визначених етапів у контексті формування професійної компетентності студентів економічних спеціальностей як важливого результату функціонування інформаційної системи;

- згідно з кожним з окреслених етапів визначення й упровадження спеціального комплексу методів щодо застосування ІСУЯО;

- експериментальна перевірка ефективності методико-технологічного забезпечення щодо упровадження ICУЯО у процесі практичного використання;

- діагностування, порівняння та аналіз динаміки сформованості професійної компетентності майбутніх економістів під час проведення констатувального i формувального експериментів; надання якісної характеристики рівням сформованості професійної компетентності студентів економічних спеціальностей, а також наукове узагальнення результатів упровадження методики застосування інформаційної системи управління якістю освіти майбутніх економістів.

План роботи передбачав такі організаційно-методичні завдання:

- відбір контрольних та експериментальних груп щодо оптимізації процесу управління якістю освіти на базі експериментальних груп;

- аналіз i порівняння отриманих статистичних даних у контрольних i експериментальних групах, а також на констатувальному і формувальному етапах подальшої експериментальної роботи;

- порівняльний аналіз динаміки формування професійної компетентності майбутніх економістів;

- оцінювання педагогічного впливу запропонованої методики застосування ICУяО на формування професійної компетентності студентів економічних спеціальностей, що засвідчує рівень керованості процесом управління якістю економічної освіти.

Відповідно до окресленого плану роботи з упровадження ICУЯО щодо відбору контрольних i експериментальних груп для участі у констатувальному i формувальному експериментах було залучено:

- загалом 204 студенти для констатувального експерименту, що навчаються за освітньо-професійними програмами бакалавра i магістра, а також 38 викладачів i співробітників університетів;

- для формувального експерименту 147 студентів, що навчаються за освітньопрофесійними програмами бакалавра i магістра, а саме - 72 респондентів в експериментальних групах (далі - ЕГ) і 75 респондентів у контрольних групах (далі КГ).

Оскільки інформаційна система управління якістю освіти майбутніх економістів була визначена як комплекс організаційно-цілеспрямовуючого, когнітивнокомпетентнісного та звітно-контрольного структурних компонентів, то послідовність етапів іiі упровадження i використання була пов'язана 3 відповідною логікою застосування і постійного покращення означених компонентів у процесі їх розробки i тестування. Важливо зазначити, що користувачам надавався доступ до тестових релізів 
програмного забезпечення (далі - ПЗ) для покращення можливостей налагодження ІСУЯО.

Під час першого - підготовчого - етапу було здійснено низку організаційновимірювальних і підготовчих заходів стосовно загального функціонування ПЗ ІСУЯО:

- налагодження відповідних параметрів функціонування ICУяО;

- внесення користувачів до системи і призначення відповідних ролей;

- надання доступу користувачам до системи з-за меж внутрішньої мережі;

Першим завданням підготовчого етапу була діяльність із запровадження ПЗ ICУЯО у даних вищих навчальних закладах. Під час підготовчого етапу проводилася інтеграція ПЗ ІСУЯО у ІКТ-інфраструктуру ВНЗ. До початку інтеграції ICУЯО у вищих навчальних закладах, що взяли участь у формувальному і констатувальному експериментах, їх ІКТ-ландшафт і комп'ютерне забезпечення було проаналізовано 3 метою виявлення можливих проблем у встановленні й налаштуванні програмного забезпечення ІСУЯО.

За необхідності, до конфігурації ПЗ вносилися зміни, що мали вплив на функціонування всієї системи. Далі до системи вносилися облікові дані користувачів, допущених до участі у проведенні експериментів. Для викладачів, методистів та інших зацікавлених учасників зі складу працівників ВНЗ, було також створено тестові облікові записи для можливості входу як студентів з метою евалуації їх пропозицій стосовно покращення відображення даних для студентів з педагогічної точки зору. На даному етапі використовувалися вербальні методи - бесіда, пояснення, інформування, а також частково використовувалася демонстрація можливостей ПЗ ICУЯО, що супроводжувалось методом надання поточних коментарів.

Під час другого етапу увага приділялася рекомендаційно-методичним заходам щодо упровадження організаційно-цілеспрямовуючого компоненту, якому в системі ICУЯО відповідає функція цілеутворення. Цей етап включав таке:

- інформаційно-методичний інструктаж групи користувачів-співробітників (адміністрації, викладачів, методистів, працівників відділу якості освіти та інших співробітників ВНЗ) щодо практичної реалізації мети, завдань та особливостей функціонування інформаційної системи;

- інформаційно-методичний інструктаж групи користувачів-студентів щодо практичної реалізації мети, завдань й особливостей функціонування інформаційної системи;

- адаптацію навчально-методичної документації до ії практичної реалізації у межах ICУЯО;

- створення допоміжної інформаційно-методичної довідникової документації для ефективного упровадження і користування ICУЯО.

Першим кроком другого етапу у розгортанні програмного забезпечення був інформаційно-методичний інструктаж груп користувачів за їх ролями (як то: викладачі, методисти, працівники відділу якості освіти, студенти). Користувачам надавалася методична інформація, що включала опис кроків з налагодження бази даних ICУяО (для адміністраторів системи), а також опис методів роботи і базової функціональності ПЗ. Означена інформація містила також основні сценарії використання програмного забезпечення у процесі прийняття рішень відносно покращення рівня якості освіти користувачами з відповідними ролями.

Було надано допомогу користувачам системи стосовно адаптації наявної навчально-методичної документації до використання в ІСУЯО, а також наведено базові приклади сформованих курсів, модулів та навчальних програм у ICУЯО. Під час ознайомлення користувачів із функціональністю й особливостями ICУЯО майбутніх економістів створювалася допоміжна i покращувалася основна інформаційно- 
методична довідникова документація на основі прямого контакту автора 3 користувачами ПЗ. Отже, було розроблено сценарії використання ПЗ ІСУЯО у процесі прийняття рішень стосовно покращення рівня якості освіти і створено низку прикладів бізнес правил для імплементації підтримки процесу прийняття означених рішень.

Тестування системи проводилося, також, самими користувачами під час роботи 3 реальними даними. Це дозволило покращити поточну діяльність веб-порталу ICУяО і спростити деякі процеси через покращення їх мапінгу (відображення) до реальних процесів у ВНЗ. У той же час важливі частини ПЗ, такі як блок бізнес-логіки і сховище даних, мали більш упорядкований процес управління релізами, що вкупі із своєю транзакційною природою практично виключало виникнення проблем із цілісністю даних. Окрім того, сховище даних було захищене від збоїв налаштованою реплікацією.

Урахування під час упровадження інформаційної системи вищезазначених позицій дозволяло швидко й ефективно забезпечити організацію економічного навчання щодо системи електронного обліку студентів, електронного розкладу аудиторних і поза-аудиторних занять, екзаменаційних сесій, навчальних модулів, електронного планування навчальних дисциплін, своєчасної реалізації загальнорегулюючої інформації (розпоряджень керівництва університету й інститутів, наказів міністерств та ін.).

Оскільки саме адаптація навчально-методичної документації і іï актуалізація у межах ICУЯО, а також інформаційно-методичний інструктаж обох груп користувачів «запускають» практичну організацію процесу економічного навчання, то II етап упровадження і використання ІСУЯО доцільно, на нашу думку, визначити як інструктивно-адаптаційний. Під час цього етапу використовувалися вербальні методи бесіди, інструктажу, поточних коментарів та інформування, а також інформаційнокомунікаційні методи адаптації документації до використання в ІСУЯО, методи евристики тощо.

Третій етап упровадження і застосування ІСУяО було присвячено когнітивнокомпетентнісному компоненту. Цей етап містив низку експериментально-методичних заходів щодо педагогічного забезпечення мотиваційно-когнітивних процесів, активізації засвоєння знань і відповідних умінь у різних галузях економічної діяльності, а також у комунікативній сфері, за рахунок відпрацювання механізму мисленнєвих операцій у процесі фахової підготовки, створення розгалуженого комплексу економічних понять тощо. Саме впродовж цього етапу відбувалось синтезування когнітивно-пізнавального i професійно-компетентнісного блоків інформаційної системи на основі актуалізації програмно-інформаційного і навчально-методичних комплексів як основи підвищення якості економічної освіти.

У контексті цього синтезування відбувались такі заходи:

- наповнення бази даних ICУяО навчально-методичними комплексами, що містять робочі і типові навчальні програми, конспект лекцій, глосарій, вимоги до проведення поточного і підсумкового контролю, інтелектуально-творчі завдання, тренінги та ін., відповідно до навчального плану ВНЗ;

- створення інформаційних пропозицій щодо побудови тестових, інтелектуально-творчих завдань тощо на основі теоретичних методів, тотожних мисленнєвим операціям (аналізу, синтезу, узагальнення, порівняння, конкретизації тощо), уніфікація форми тестових завдань;

- інформаційне забезпечення щодо електронної бібліотеки економіста, яке містить комплекс відповідних електронних підручників і посібників, комплексного електронного глосарію економіста та ін.;

- створення бази інформаційних повідомлень щодо проведення науковопрактичних конференцій, семінарів 3 проблем теорії і практики економічної науки, 
економічного розвитку суспільства тощо 3 отриманням відповідних інформаційних листів;

- інформаційне забезпечення створення електронних видань наукових студентських робіт; HTTM;

- створення електронної репрезентації наявних студентських пошукових гуртів

- формування інформаційної основи для прийняття рішень щодо підвищення рівня якості освіти і допомагає користувачам приймати рішення щодо запровадження коригуючих дій з метою покращення якості освіти.

Доцільно розглянути означені заходи більш детально.

До початку другого етапу користувачі ІСУЯО мали змогу отримати знання для продуктивного використання даної системи у процесі покращення якості освіти у своїх ВН3. На цьому етапі користувачі займалися наповненням бази даних ІСУяО навчально-методичними комплексами, включно з робочими навчальними програмами, конспектами лекцій, електронними презентаціями, вимогами до проведення контролю тощо.

Система має змогу частково інтегруватися із системою дистанційного навчання (далі - СДН) Moodle (за умови використання нею баз даних на основі MS SQL Server). Отже, може бути досягнутий позитивний вплив на якість вищої освіти від поєднання обох систем за рахунок використання випробуваних на практиці систем. ПЗ ІСУЯО в даному випадку відповідала за збереження даних оцінювання й теоретичних i методичних довідкових матеріалів і пропозицій, на базі яких формувалися тестові завдання.

У межах завдання 3 інформаційного забезпечення створення електронної бібліотеки економіста було інтегровано структуру модулів і курсів електронні підручники і посібники, що могли використовуватися студентами у підготовці до відповідних занять в межах означених курсів.

До блоку новин на порталі ІСУЯО вносилися інформаційні повідомлення щодо проведення науково-практичних конференцій у рамках університетів-учасників експериментів, а також різноманітних семінарів. Причому означені повідомлення формувалися 3 урахуванням цільового відображення для користувачів із певними ролями. Отже, забезпечувався принцип відображення лишень релевантної інформації для кінцевих груп користувачів.

У межах наявних наукових проектів університетів проводилося інформаційне забезпечення щодо створення електронних видань наукових студентських робіт. В єдиній структурі курсів і модулів, представлених у ВНЗ в ІСУЯО створювалися елементи для електронних студентських видань. Функціональність ICУЯО дозволила сформувати електронний документообіг для підтримки організації створення студентських видань. Програмні функції блоку новин інтернет-порталу ІСУЯО дозволили також провадити цільове інформування учасників про вихід нових випусків видань. Аналогічно формувалися електронні репрезентації наукових студентських гуртків. ПЗ ІСУЯО дозволило також запровадити електронний розклад для зустрічей гуртків. Отже, за допомогою інформаційного наповнення бази даних ICУЯО створювалася основа для прийняття рішень всіма користувачами даного програмного забезпечення. Окрім цього, на основі генералізованих і спеціалізованих процесів 3 підвищення рівня якості, усталених у означених ВНЗ було сформовано основні бізнес правила і визначено поведінку системи за зміни певних показників системи.

Оскільки на третьому етапі відбувалось повноцінне наповнення баз даних інформацією щодо відповідного навчально-методичного матеріалу, то даний етап упровадження ІСУЯО було нами визначено як методично-базовий. Серед методів, що 
використовувалися під час цього етапу, доцільно виділити: педагогічні спостереження, бесіди, тренінги тощо. Серед інформаційно-комунікаційних методів було використано аналіз усталених процесів ВНЗ, формування електронної комунікації.

Під час четвертого етапу проводилися заходи, які передбачали, що ICУяО майбутніх економістів уже $є$ цілком налагодженою. Означені заходи передбачали:

- тестування системи в режимі реального часу;

- евалуацію й оцінювання користувачами власного досвіду використання системи;

- запровадження запропонованих змін у результаті комунікації з користувачами ПЗ ІСУЯО;

- проведення формувального експерименту щодо розвитку професійної компетентності майбутніх економістів.

Означені заходи мали одночасний характер і були реалізовані через процеси перманентного покращення системи i комунікації із зацікавленими особами i користувачами. Важливе значення в даному випадку мав зворотній зв'язок користувачів з автором програмного забезпечення, адже в такий спосіб створювалися можливості щодо кращого розуміння потреб користувачів системи і щодо іiі оптимізації. Також, на даному етапі проводився формувальний експеримент щодо розвитку професійної компетентності майбутніх економістів. У процесі цього експерименту необхідно було визначити необхідні заходи для подальшого вдосконалення якості освіти. Враховуючи означені заходи, доцільно було визначити даний етап як експериментально-евалуаційний. До методів, що використовувалися під час цього етапу, було включено такі: методи математичної статистики, вербальні, інтерактивні, теоретичні, бінарні, емпіричні методи (анкетування, діагностичні опитування, евристично-аналітичні тренінги, тестування тощо), методи контролю й самоконтролю, інформаційно-комунікаційні форми, засоби і методи економічного навчання тощо.

\section{4. ВИСНОВКИ ТА ПЕРСПЕКТИВИ ПОДАЛЬШИХ ДОСЛІДЖЕНЬ}

Наукове узагальнення проведеної дослідно-експериментальної роботи дозволяє зробити такі висновки. Зміст організаційної роботи щодо упровадження методикотехнологічного забезпечення ICУЯО майбутніх економістів включає чотири етапи (підготовчий, інструктивно-адаптаційний, методично-базовий, експериментальноевалуаційний) і містить: ІСУЯО;

- сукупність методико-технологічних заходів для кожного з етапів упровадження

- комплекс вербальних, теоретичних, емпіричних, інформаційнокомунікаційних, інтерактивних, евристичних, бінарних та інших методів застосування ІСУЯО;

- експериментальну перевірку ефективності методико-технологічного забезпечення; діагностування;

- порівняння й аналіз динаміки сформованості професійної компетентності майбутніх економістів;

- наукове узагальнення результатів упровадження методики застосування інформаційної системи управління якістю освіти майбутніх економістів.

Подальші заходи щодо упровадження методико-технологічного забезпечення ICУЯО майбутніх економістів передбачають створення педагогічно описовофункціональної моделі ІСУяО, яка, з одного боку, окреслює цілі, структуру, принципи 
функціонування, з іншого боку, містить відображення функціональних зв'язків як між структурними компонентами системи, так з освітнім середовищем через відповідні педагогічні умови, наукові підходи, визначення етапи застосування.

\title{
СПИСОК ВИКОРИСТАНИХ ДЖЕРЕЛ
}

1. Закон України «Про вищу освіту» // Відомості Верховної Ради України. — 2014. — №37-38.

2. Національна стратегія розвитку освіти в Україні на період до 2021 року, схвалена Указом Президента України від 25 червня 2013 року №344/2013.

3. Хоружий К. С. Компонентна структура і функції інформаційної системи управління якістю освіти майбутніх економістів [Електронний ресурс] / К. С. Хоружий // Інформаційні технології і засоби навчання. - 2014. - № 4 (42). - С. 168-180. - Режим доступу : http://journal.iitta.gov.ua/index.php/ittl/article/view/1068\#.VCxtehbgWSo.

4. Хоружий К. С. Сучасні вимоги до системи управління якістю освіти в контексті вітчизняного i світового досвіду / К. С. Хоружий // Вища освіта України: теоретичний та науково-методичний часопис. № 2 (додаток 2). - 2013. - Тематичний випуск «Науково-методичні засади управління якістю освіти у вищих навчальних закладах». - Луцьк : СПД Гадяк Жанна Володимирівна, «ВолиньПоліграф» ТМ. - С. 75-80;

5. Національна доповідь про стан і перспективи розвитку освіти в Україні / В. П. Андрущенко, І. Д. Бех, М. І. Бурда та ін.; за ред. В. Г. Кременя. — К .: Педагогічна думка, 2011. — С. 36-47.

Матеріал надійшов до редакциї 02.12.2014p.

\section{СОДЕРЖАНИЕ МЕТОДИКО-ТЕХНОЛОГИЧЕСКОГО ОБЕСПЕЧЕНИЯ ИНФОРМАЦИОННОЙ СИСТЕМЫ УПРАВЛЕНИЯ КАЧЕСТВОМ ОБРАЗОВАНИЯ БУДУЩИХ ЭКОНОМИСТОВ}

\author{
Хоружий Константин Сергеевич \\ аспирант \\ НПУ им. М. П. Драгоманова, г. Киев, Украина \\ kothor88@gmail.com
}

\begin{abstract}
Аннотация. В статье рассмотрены содержание и сущность организационной работы по применению методико-технологического обеспечения информационной системы управления качеством образования (ИСУЯО) будущих экономистов. Содержание организационной работы по внедрению методико-технологического обеспечения ИСУЯО будущих экономистов включает четыре этапа (подготовительный, инструктивноадаптационный, методически базовый и экспериментально-эвалуацийний) и содержит совокупность методико-технологических мероприятий для каждого из этапов внедрения ИСУЯО. Проведено исследование педагогического воздействия предложенной методики применения ИСУЯО на формирование профессиональной компетентности студентов экономических специальностей. Определены основные этапы, комплекс методов и последовательность организационных мероприятий по внедрению методико-
\end{abstract} технологического обеспечения ИСУЯО.

Ключевые слова: информационная система управления качеством образования; содержание методико-технологического обеспечения, организационная работа; подготовительный; инструктивно-адаптационный; методически-базовый; экспериментально-эвалуационный этапы; комплекс методов; методико-технологические мероприятия. 


\title{
CONTENTS OF THE METHODOLOGICAL AND TECHNOLOGICAL SUPPORT OF THE EDUCATION QUALITY MANAGEMENT INFORMATION SYSTEM FOR FUTURE ECONOMISTS
}

\author{
Kostiantyn S. Khoruzhyi \\ postgraduate student \\ National Pedagogical Dragomanov University, Kyiv, Ukraine \\ kothor88@gmail.com
}

\begin{abstract}
In the article, the content and nature of organizational activities in scope of methodological and technological support of the education quality management information system (EQMIS) for future economists are described. The content of the organizational activities for the implementation of methodological and technological support of EQMIS for future economists includes four stages (preparatory, instructional/adaptational, methodological/basic, as well as experimental/evaluational) and contains a set of methodological and technological measures for each of the stages of the EQMIS implementation. A study of the pedagogical impact of the proposed methodology of using EQMIS in the formation of professional competence of economics students was also conducted. The main stages, methods and sequence of implementation arrangements for the methodological and technological support of EQMIS are defined.
\end{abstract}

Keywords: education quality management information system; content of methodological and technological support; organizational activities; preparatory; adaptive-instructional; methodological and foundational; evaluation and experimental stages; methodology; implementation arrangements.

\section{REFERENCES (TRANSLATED AND TRANSLITERATED)}

1. The Law of Ukraine "On Higher Education" // Supreme Council of Ukraine. — 2014. — №37-38 (in Ukrainian).

2. The National Strategy for the Development of Education in Ukraine until 2021, approved by the Decree of the President of Ukraine on June 25, 2013 №344 / 2013 (in Ukrainian).

3. Khoruzhyi K. S. Component structure and function of the education quality management information system of future economists [online] / K.S. Khoruzhyi // Information Technologies and Learning Tools. - 2014. - № 4 (42). $\quad$ - $\quad$ P. $\quad 168-180 . \quad$ - Available from : http://journal.iitta.gov.ua/index.php/itlt/article/view/1068\#.VCxtehbgWSo (in Ukrainian).

4. Khoruzhyi K. S. Modern requirements for a quality management system of education in the context of domestic and international experience / K.S.Khoruzhyi // Higher education of Ukraine: theoretical and scientific-methodical journal. №2 (Appendix 2). — 2013. - Thematic issue of "Scientific and Methodological Foundations of education quality management in higher education. — Lutsk : Hadyak Zhanna Volodymirivna Ltd. "VolynPolihraf" TM. - P. 75-80 (in Ukrainian).

5. National Report on the status and prospects of education in Ukraine / V. P. Andrushchenko, I. D. Bech, M. I. Burda, etc.; eds. V.G.Kremen. — K. : Pedagogical Thought, 2011. — P. 36-47 (in Ukrainian). 